\title{
Aplikasi Absensi Siswa Untuk Kemudahan Informasi Antara Pihak Sekolah dan Orang Tua pada Sekolah Dasar Negeri 3 Banda Aceh Berbasis Android
}

\author{
Student Attendance Application For Ease of Information Between Schools and \\ Parents in Banda Aceh State Primary School 3 Based on Android \\ Dini Faradilla ${ }^{1}$, Zalfie Ardian ${ }^{2}$ \\ Prodi Teknik Informatika Fakultas Ilmu Komputer, Universitas Ubudiyah Indonesia \\ Jl. Alue Naga Tibang. Kec. Syiah Kuala, Banda Aceh, Indonesial dan 2 \\ Email: dinifaradilla@gmail.com ${ }^{1}$,Zalfie.ardian@uui.ac.id ${ }^{2}$
}

\begin{abstract}
Abstrak
Absensi adalah sebuah kegiatan pengambilan data guna mengetahui jumlah kehadiran pada suatu pelajaran, setiap kegiatan yang membutuhkan informasi mengenai siswa tentu akan melakukan absensi. Sistem absensi berbasis android ini dirancang berdasarkan hasil pengamatan dan wawancara kepada guru dan orang tua perihal kehadiran siswa Sekolah Dasar Negeri 3 Banda Aceh. Tujuan pembuatan aplikasi absensi siswa berbasis android diharapkan dapat mempermudah guru dalam mengabsen siswa dan menghitung jumlah kehadiran siswa. Metode pengujian aplikasi yaitu menggunakan metode blackbox. Aplikasi ini dirancang dengan menggunakan Android Studio sebagai media pembuatannya dengan bahasa pemograman java, SQL sebagai database penyimpanan kata dan kemudian diimplementasikan ke smartphone berbasis android. Dari hasil quesioner didaptkan bahwa hampir sekita 81\% menggunakan sistem aplikasi absensi berbasis android memberi guru kontrol lebih besar atas pekerjaannya dan $89 \%$ mempermudah orang tua untuk mendapatkan informasi absensi siswa.
\end{abstract}

Kata Kunci : Absensi, Smartphone, Android, Android Studio, SQL

\begin{abstract}
Attendance is a data collection activities in order to determine the amount of attendance at a lesson, any activity that requires information about the student would confirm their attendance. This android based attendance system is designed based on observations and interviews with teachers and parents about the presence of public elementary school students 3 Banda Aceh. The purpose of making the student attendance android based applications is expected to facilitate the roll of students and teachers in counting the number of student attendance. Penguian method of application that is using the blackbox. This application is designed to use Android Studio as a media creation with java programming language, SQL as the database storage of words and then implemented android based smartphone. From the results of questionnaires be obtained that almost About a $81 \%$ attendance system using android based application gives teachers more control over their work and $89 \%$ easier for parents to get student attendance information.
\end{abstract}

Keyword : Absent, Smartphone, Android, Android Studio, SQL

\section{PENDAHULUAN}

1. Latar Belakang

Sekolah merupakan sebuah

lembaga pendidikan yang formal yang didirikan oleh Negara dan dirancang untuk mengajari siswa dengan bimbingan dari guru (mengajar atau mendidik, 1998:21) Sekolah Dasar Negeri 3 (SD N 3) Banda Aceh berdiri pada tahun 1957. Sekolah yang berlokasi di Provinsi Nanggroe Aceh Darussalam (NAD) Kabupaten Kota Banda Aceh dengan alamat
Jalan. Tgk. Chik Ditiro. Sekolah ini berakreditasi A dengan jumlah guru 30 orang dan jumlah siswa 553 orang. 
Journal of Informatics and Computer Science Vol. 4 No. 2 Oktober 2018

Universitas Ubudiyah Indonesia

e-ISSN : 2615-5346

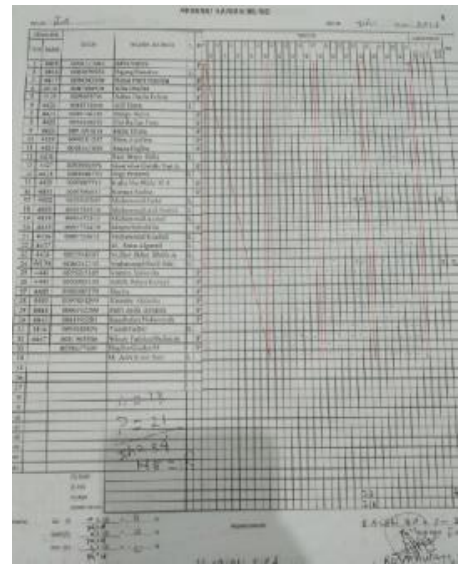

Gambar 1 Absensi Manual yang digunakan SD Negeri 3 Banda Aceh (sumber : Pribadi)

Salah satu indikator penunjang siswa di SD N 3 Banda Aceh yaitu absensi siswa yang dilakukan setiap hari pada setiap mata pelajaran. Saat ini SD N 3 Banda Aceh masih menggunakan absensi manual, pada gambar 1.1 terdapat contoh gambar absensi manual pada SD N 3 Banda Aceh.

Guru setiap hari melakukan absen siswa dengan membuat keterangan hadir atau tidak hadir dengan menggunakan pulpen pada buku absensi manual dan mengghitung jumlah kehadiran siswa, dihitung berdasarkan jumlah siswa yang hadir. Absen dengan cara manual memiliki beberapa kekurangan antara lain yaitu saat terjadinya bencana alam, sulitnya pengarsipan dan sulit dalam merekap absensi siswa. Disinilah peranan sistem absensi database terintegrasi, penyediaannya terkomputerisasi yang mampu menampilkan rekapan kehadiran siswa untuk keperluan guru maupun untuk keperluan orang tua agar dapat melihat data kehadiran ananknya.

Sistem absensi berbasis android ini dibuat karaena mayoritas dari guru dan orang tua di SD Negeri 3 Banda Aceh sudah menggunakan smartphone android. Penggunaan smartphone android ini semakin hari semakin meningkat, khusus di Indonesia menurut survei penggunaan smartphone android dari tahun 2013 hingga tahun 2018 semakin meningkat. Grafik penggunaan smartphone android dapat dilihat pada gambar 1.2, sistem absensi dibuat sebagai sarana yang diharapkan dapat mempermudah guru dalam merekap absensi siswa.

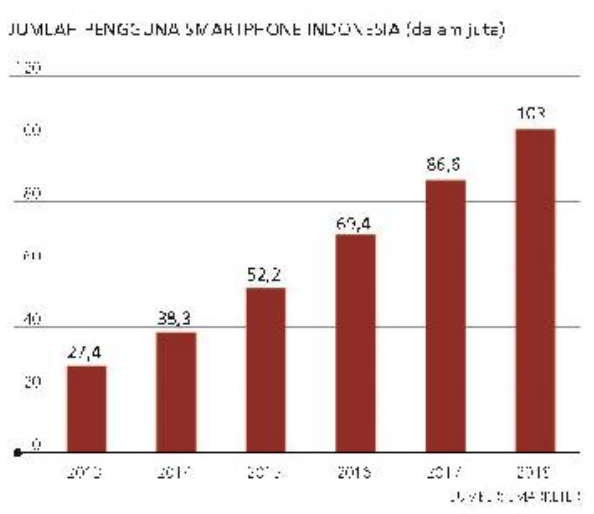

Gambar 2 Grafik Penggunaan Smartphone di Indonesia

\section{Tinjauan Pustaka}

Menurut Imron peserta didik yang hadir disekolah hendaknya dicatat oleh guru dalam buku presensi sementara peserta didik yang tidak hadir disekolah dicatat dalam buku absensi. Dengan kata lain presensi adalah mencatat kehadiran sedangkan absensi mencatat ketidak hadiran. Begitu jam pertama sudah masuk peserta didik di panggil satu persatu oleh guru (Imron, 1994)

Menurut Safaat 2012, android merupakan generasi baru platform mobile, platform yang memberikan pengembangan untuk melakukan pengembangan sesuai dengan yang diharapkan. Sistem operasi yang mendasari android dilesensikan dibawah GNU, General Public License Versi 2 (GPL 2), yang lebih dikenal dengan istilah copyleft, lisensi dimana setiap perbaikan pihak ketiga harus terus dibawah syarat (terms), Android didistribusikan dibawah License Apache Software yang memungkinkan untuk dstribusi kedua dan seterusnya. Komersialisasi pengembangan dapat memilih untuk meningkatkan platform tanpa harus memberikan perbaikan mereka ke masyarakat open source. Sebaiknya pengembangan dapat keuntungan dari perangkat tambahan seperti penaikkan dan mendistribusikan ulang pekerjaan mereka dibawah lisensi apappun yang mereka inginkan (safaat, 2012).

3. Teknik Pengumpulan Data

Untuk memperoleh data-data yang diperlukkan dalam mencapai kesempurnaan dan kelengkapan proposal tugas akhir ini, maka dapat dilihat pada diagram alur penelitian gambar . 
Journal of Informatics and Computer Science Vol. 4 No. 2 Oktober 2018

Universitas Ubudiyah Indonesia

e-ISSN : 2615-5346

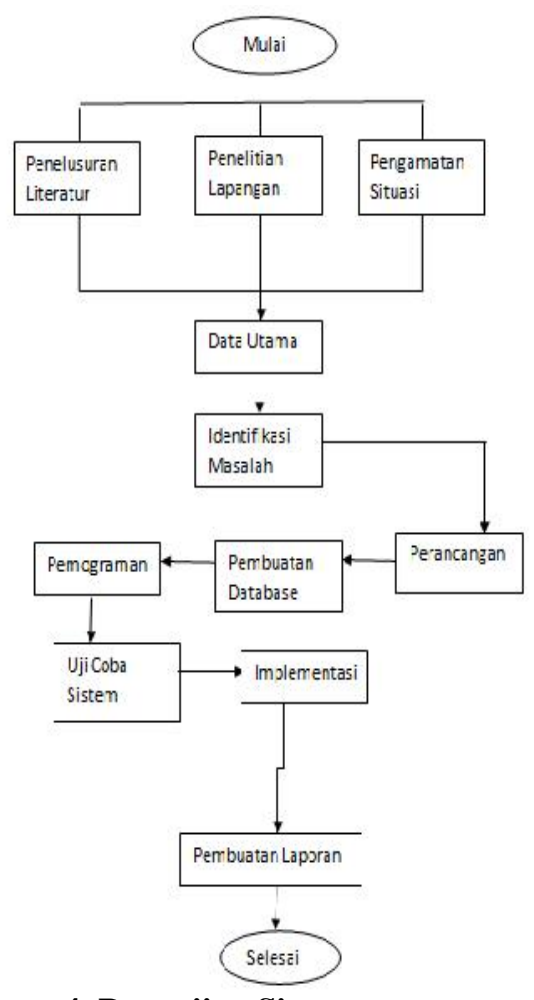

\section{Pengujian Sistem}

Berdasarkan rencana pengujian yang telah disusun, maka dapat dilakukan tahapan pengujian sebagai berikut :

1. Pengujian Fitur Utama

Pengujian fitur utama yaitu menu absensi, guru akan melakukan absensi dan menyimpan kehadiran siswa pada database. Gambar dpat dilihat pada gambar.

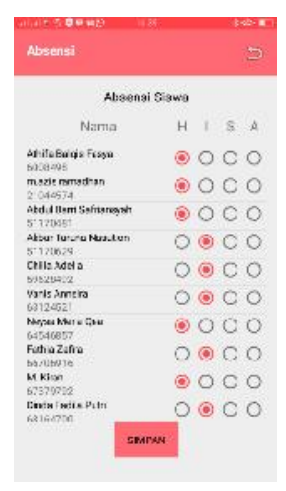

2. Pengujian Kelayakan Aplikasi

Kelayakan aplikasi di implemntasikan pada 3 smartphone, implemntasi sebagai berikut : a. Menggunakan Smartphone OPPO F1S

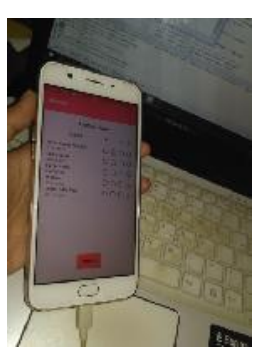

Gambar Pengujjian dengan

Smartphone Oppo F1s

b. Menggunakan Xiomi Redmi 3

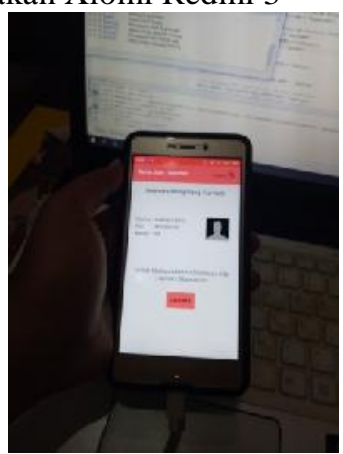

Gambar Pengujian dengan Smartphone Xiomi Redmi 3

c. Menggunakan Samsung Tab 3

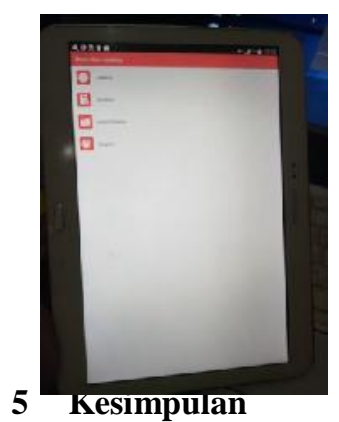

Berdasarkan hasil pembahasan dan pengujian sistem Rancang Bangun Aplikasi Sistem Absensi Siswa Berbasis Android dapat disimpulkan bahwa:

1.Aplikasi absensi siswa berbasis android dirancang menggunakan android studio dengan bahsa pemograman java dan database SQL.

2.Aplikasi absensi siswa berbasis android dapat berjalan diberbagai smartphone, hal ini dibuktikan berdasarkan pengujian aplikasi pada 3 smartphone yaitu OPPO F1S, Xiomi Redmi 3 dan Samsung Galaxy Tab 3.

3.Berdasarkan hasil pengujian perancangan aplikasi absensi siswa berbasis android berhasil memberi 
Journal of Informatics and Computer Science Vol. 4 No. 2 Oktober 2018

Universitas Ubudiyah Indonesia

e-ISSN : 2615-5346

pemberitahuan kehadiran siswa

Daftar Pustaka

[1] Armi Jusitia dan Barry Nuqoba (2014). Parential Control Sistem Pada Boarding School Berbasis Android.

[2] Dika Nurul Handayani (2013). Merancang Sistem Karyawan Berbasis SMS Getway

[3] Gilifillan, Ian. 2003. PostgreSQL vs MySQL : Which is Better? MySQL, South Afrika

[4] I Made Dharma Susila (2013). Sistem Absensi Mahasiswa Menggunakan Absensi Barcode Berbasis Android.

[5] Kadir, Abdul. 2013. Pemograman Database MySQL. Mediakom. Yogyakarta.

[6] Liverdink, P. 2009. Web and SQL Service. Apress, USAMeier, R. 2009. Professional Android Aplication Canada

[7] M. Taqwa Muddin dan Diana Laily Fitri (2015). Sistem Absensi Asisten Dosen Menggunakan QR. Code Scanner Berbasis Android pada Program Studi Sistem Informasi Universitas Muna Kudus.

[8] Parno, 2011 : Aplikasi Mobile Kamus Istilah Psikologi Berbasis Android 2.2. Procedding PESAT (Psikologi Ekonomi, Sastra, Arsitektur dan Sipil) 4(3)

$: 123$

[9] Riyanto, 2010. Membuat Sendiri Aplikasi Mobile SIG- Platform Java ME, Blackberry dan Android. Andi Publisher, Yogyakarta.

[10] Raulan Samosir (2013). Perancangan Sistem Absensi Berbasis Android.

Safaat, N. 2012. Android

[11] Pemograman Aplikasi Mobil Smarthone dan Tablet PC Berbasis Android. INFORMATIKA. Bandung.

[12] Shih, George and Nagy, Paul. 2010. Is Android or Iphone the Plaform for Innovation in Imaging Informatic. Jurnal Of Digital Imaging, New York. [13] www.pengayaan.com, diakses pada tanggal 13November 2016

[14] www.theinspirationroom.c om, diakses

pada tanggal 17

November 2016

[15] www.seklogo.com,diakses pada tanggal 17 November 2016

[16] www.technocollit.com , diakses pada tanggal 17

November 2016 kepada orang tua.

Development. Wiley Publishing, [17] www.otreva.com, diakses pada tanggal 17 November 2016

[18] www.json.org diakses, 22 Maret 2017, 19 
Journal of Informatics and Computer Science Vol. 4 No. 2 Oktober 2018

Universitas Ubudiyah Indonesia

e-ISSN : 2615-5346 